\title{
Metody modelowania pracy zaworów rozrządczych pojazdów szynowych
}

\begin{abstract}
Zaprezentowano różne metody modelowania pracy zaworów rozrzqdczych pneumatycznego hamulca pojazdu szynowego. Bazuja one na podziale uktadu na dyskretne elementy, opisie działania wewnatrz elementu $i$ współdziałania między nimi $w$ różnym stopniu uproszczenia, zlożeniu $w$ uklad i rozwiqzaniu poprzez symulacje czasowq. Propozycja różnych stopni dokładności modelowania wynika z celów praktycznych, dla których może być wykorzystana. Przedstawiono wybrane modele i porównanie wyników pomiarów z symulacja. Artykut powstat w wyniku realizacji projektu badawczego KBN $\mathrm{nr} 5 T 12 \mathrm{C03025}$ pt. „Badania procesów zachodzacych w pneumatycznych układach hamulcowych pociqgów".
\end{abstract}

\section{Wstęp}

Elementem sterującym w układzie pneumatycznym hamulca wagonu kolejowego jest zawór rozrządczy. Jego głównym zadaniem jest sterowanie ciśnieniem w cylindrze hamulcowym w zależności od zmian ciśnienia $\mathrm{w}$ przewodzie głównym i napełnianie zbiornika pomocniczego. Jednakże rzeczywisty zakres jego funkcji jest bardziej rozwinięty. Dodatkowo zawór podlega wymaganiom wynikającym z konieczności właściwego współdziałania $\mathrm{z}$ już homologowanymi zaworami, a wiele wymagań jest skodyfikowanych w przepisach międzynarodowych (kartach UIC). Poza spełnieniem norm zawór rozrządczy winien wykazywać wiele cech kwalifikujących go do miana nowoczesności (dokładność pracy, brak histerezy, odpowiednia czułość, odporność na przepełnienia zbiornika sterującego, tzn. wzrost $\mathrm{w}$ nim ciśnienia ponad ciśnienie w przewodzie głównym (PG) w pozycji ,jazda"). Oprócz tego zawór winien spełniać wymagania technologiczne (m.in. niskie koszty wytwarzania). Musi również posiadać zalety eksploatacyjne:

- dużą żywotność oznaczającą małe zużycie

- brak starzenia elementów i brak korozji

- odporność na uszkodzenia i wibracje występujące w pojeździe

- dużą odporność na zanieczyszczenia i zawilgocenie powietrza.

Skonstruowanie nowoczesnego zaworu jest złożonym przedsięwzięciem konstrukcyjno-badawczym. Zawór rozrządczy przed dopuszczeniem do eksploatacji musi zostać poddany homologacji.

$\mathrm{Z}$ podanych względów jedynie kilku producentów posiada odpowiedni potencjał do wdrażania nowych zaworów rozrządczych, natomiast kilka innych firm produkuje zawory rozrządcze na podstawie licencji. W ostatnich latach dokonują się przekształcenia własnościowe wśród producentów.

Dla użytkownika wybór zaworu rozrządczego wiąże się z jego wieloletnią eksploatacją i koniecznością zapewnienia bazy serwisowej, co może wiązać się ze znacznymi kosztami.
Określenie „zawór rozrządczy” jest umowne, gdyż w skład analizowanego kompletu zaworów rozrządczych wchodzą:

- zawór maszynisty pojazdu trakcyjnego, sterujący pracą całego układu

- przewód główny

- zawór rozrządczy (w wagonie osobowym lub towarowym)

- zbiorniki hamulcowe

- cylindry hamulcowe

- komory powietrzne.

Zarówno dla oceny istniejących zaworów, jak i w trakcie prac projektowych należy dokonać różnorodnych analiz układu hamulcowego oraz zebrać charakterystyki pracy elementów (zbiorników i cylindrów) układu. Można to zrealizować poprzez rejestrację pomiarów doświadczalnych albo poprzez symulację komputerową.

Celem artykułu jest przedstawienie opracowanych przez autora różnych przykładów metod modelowania zaworów rozrządczych, zweryfikowanych na podstawie pomiarów doświadczalnych seryjnego zaworu.

\section{Cel modelowania poszczególnych zaworów roz- rządezych}

Aby móc ocenić zalety danego zaworu należy dokonać jego przetestowania na rzeczywistym pociagu w różnych warunkach. Nie zawsze jest to możliwe lub opłacalne. Można dokonać tego również w ograniczonym zakresie na stanowisku pomiarowym lub/i metodami analitycznymi, głównie poprzez symulację.

Celem modelowania i symulacji może być:

- posiadanie uproszczonego narzędzia symulacyjnego (np. dla celów dydaktycznych)

- rozpoznanie działania zaworu rozrządczego i ocena różnych rozwiązań aparatów hamulcowych, gdyż nie zawsze słowny opis działania pozwala na wychwycenie wszystkich uwarunkowań konstrukcyjnych, a czasem pominięte są $\mathrm{w}$ opisie firmowym uwarunkowania prawidłowego działania układu 
- $\quad$ przewidywanie poprzez analizy symulacyjne zachowania zaworu w nietypowych sytuacjach, gdy brak jest możliwości przeprowadzenia prób stanowiskowych

- wspomaganie procesu projektowego; w tym przypadku nie istnieje jeszcze fizycznie zawór, a analiz dokonuje się metodami symulacyjnymi; pozwala to wyeliminować niekorzystne warianty konstrukcji, radykalnie zmniejszyć ilość drogich prototypów i ich badań oraz przyspieszyć proces projektowy

- $\quad$ zabudowanie modelu zaworu jako części modelu całopociagowego [1] pozwala na wspomaganie lub symulacje badań całopociagowych. Badania takie przeprowadzane zarówno na torze kolejowym jak i na stanowisku stacjonarnym są bardzo kosztowne. Analizy symulacyjne są dużo tańsze, pozwalają na przeprowadzanie analizy czułości układu i odporności na przepelnienia zbiornika sterującego po odhamowaniu uderzeniowym składu pociągu oraz nietypowych analiz, np. współdziałanie $\mathrm{w}$ jednym pociąu zaworów rozrządczych różnych producentów. Mogą dodatkowo być fragmentem jeszcze większych modeli, np. do obliczeń trakcyjnych, czy rozkładu jazdy.

Przedstawione cele modelowania wskazują pośrednio na różne wymagania co do dokładności modelu.

Dokładność modelowania należy rozpatrywać również z drugiej strony - od strony kosztów (pracochłonności) i trudności budowy modelu. Model prosty można zbudować praktycznie $\mathrm{w}$ oparciu o firmowe materiały poglądowe o zaworze i tablice prób odbiorczych. Model bardzo dokładny wymaga korzystania z rysunków konstrukcyjnych, a nawet dokonania niestandardowych badań stanowiskowych zaworu; program symulacyjny dokładnego modelu jest również bardziej skomplikowany $\mathrm{w}$ obsłudze i wielokrotnie dłużej liczący.

\section{Metodyka modelowania zaworów rozrządczych}

Zawór rozrządczy hamulca kolejowego jest skomplikowanym układem łączącym wiele elementów pneumatyczno-mechanicznych, przelączającym samoczynnie swe działanie w zależności od stanu połączonych z nim: przewodu głównego (PG), zbiornika sterującego, cylindra hamulcowego i zbiornika pomocniczego.

Zasadniczą częścią współczesnych zaworów jest tzw. główny przyrząd rozrządczy, sterujący ciśnieniem $\mathrm{w}$ cylindrze hamulcowym zasilanym ze zbiornika pomocniczego lub opróżnianym do atmosfery $\mathrm{w}$ zależności od wartości ciśnień $\mathrm{w}$ przewodzie głównym i zbiorniku sterującym. Przepływ powietrza jest regulowany zaworem mającym podwójny przelot sterowany zaworkiem trójdrożnym, złożonym $\mathrm{z}$ siedzenia, trzona drazżonego i zaworka. Jego schemat przedstawiono na rys. 1 .

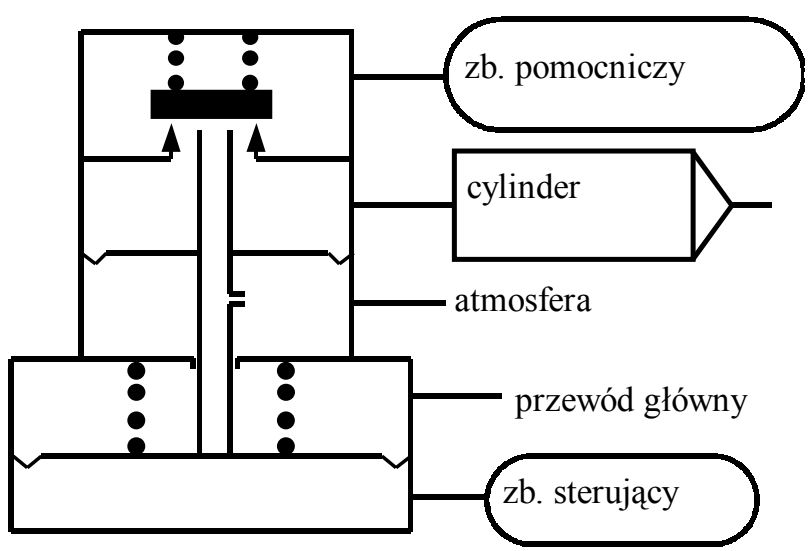

Rys. 1. Schemat głównego przyrządu rozrządczego

W zależności od celu analiz symulacyjnych sposób modelowania może być różny:

a) Do opisu zachowania się zaworu w procesach hamowania i odhamowania model może być uproszczony; jedynie przebieg ciśnienia $\mathrm{w}$ cylindrze $\mathrm{w}$ funkcji czasu winien być możliwie wierny.

b) Do symulacji zachowania się zaworu w różnych sytuacjach modelowanie winno odwzorowywać reakcje zaworu na wszelkie możliwe sterowania ( nie zawsze zamierzone). Dotyczy to np. sytuacji nietypowych jak nieszczelny układ pneumatyczny, przerywane sterowania zaworu, granice czułości i nieczułości, przepełnienie zbiornika sterującego $\mathrm{w}$ trakcie uderzeniowego napelniania przewodu głównego.

c) Analiza konstrukcji danego zaworu możliwa jest przez symulacje na modelu najbardziej dokładnym, w którym należałoby uwzględnić również zjawiska termiczne w układzie oraz dynamikę elementów ruchomych. Możliwe jest to np. przez użycie opracowanego przez autora pakietu BLOK [6], ukierunkowanego na symulację układów hamulcowych lub innych uniwersalnych metod.

Oprócz głównego przyrządu rozrządczego, zawór rozrządczy może posiadać różnorodne inne układy pneumatyczno-mechaniczne:

- napełniania i regulacji ciśnienia $\mathrm{w}$ dołączonych zbiornikach, z zapewnieniem odpowiedniej niewyczerpalności hamulca i zabezpieczenia przed przepełnieniem zbiornika sterującego $\mathrm{w}$ trakcie uderzeniowego napełniania przewodu głównego

- przyspieszacz, powodujaccy chwilowy upust powietrza z przewodu głównego przy pierwszym hamowaniu; jest on związany funkcyjnie $\mathrm{z}$ elementami zapewniającymi odpowiednią czułość i nieczułość zaworu rozrządczego

- elementy sterujące prędkością napełniania i opróżniania cylindra i zbiorników (ewentualnie ich przestawiacze)

- przyrząd zaskoku ciśnienia w cylindrze

- przekładnik do ujednolicania czasów napełniania i luzowania cylindra bez względu na jego wielkość 
- elementy likwidacji przepełnienia zbiornika sterującego

- odluźniacz i inne.

Cechą charakterystyczną zaworów rozrządczych jest częste sprzężenie działania elementów składowych i wielofunkcyjność działania, pozwalające na zmniejszenie ilości elementów, ale utrudniające modelowanie działania takiego układu.

Modelowanie działania układu winno zapewnić określenie przebiegu zmienności parametrów (w zbiornikach - ciśnienia, a w cylindrze - ciśnienia i przemieszczenia tłoka) we wszystkich elementach zewnętrznych, które są sterowane ciśnieniem w przewodzie głównym. Dlatego też pojęcie modelowania zaworu rozrząadczego dotyczy praktycznie całego układu pneumatycznego hamulca wagonu.

W czasach, kiedy komputery nie były rozpowszechnione, układy hamulcowe modelowano metodami analogowymi. Nieliniowości układu i znaczne jego skomplikowanie powodowały, że dokładność analiz była ograniczona. Obecnie pojęcie modelowania dotyczy głównie symulacji cyfrowych. Ponieważ rozważa się głównie procesy przejściowe $\mathrm{z}$ różnymi przełączeniami działania układu, ograniczone jest ono do symulacji przebiegów w funkcji czasu procesu.

\section{Ogólne zależności termodynamiczne opisujące przemiany gazu}

Użyte w pkt 4 symbole i oznaczenia są zgodne z podanymi w publikacji [6].

Działanie pneumatycznego układu hamulcowego polega $\mathrm{w}$ istocie na przepływach powietrza między poszczególnymi elementami układu, dławionych różnego typu elementami oraz napełnianiu i opróżnianiu różnych pojemności. Ograniczanie strumieni przepływu dokonywane jest przeważnie zaworami grzybkowymi i dyszami. Dysze w zaworze rozrządczym są przeważnie cylindryczne, bez zaokraglania krawędzi i dyfuzorów, dlatego nie pojawia się nadkrytyczna prędkość gazu. Gdyby nawet pojawiła się, to na krótkim odcinku przepływu następuje przeskok do prędkości krytycznej i prędkość nadkrytyczną można pominąć.

Pewnym problemem jest wymiana ciepła w zbiornikach i przewodach łączących. Gaz przepływając przez dysze zmienia temperaturę, która wyrównuje się cześciowo do temperatury otoczenia poprzez ścianki przewodów. Samo dostarczanie lub pobór gazu ze zbiornika, zgodnie z zasadami bilansu energii układu otwartego, zmienia również jego temperaturę. Wyrównuje się ona $\mathrm{z}$ otoczeniem $\mathrm{z}$ przebiegiem czasu. W układzie rzeczywistym zjawisko jest skomplikowane, gdyż oziębiający się podczas rozprężania gaz w zbiorniku (np. pomocniczym) jest częściowo ogrzewany przez ścianki zbiornika i przewody, następnie oziębiany przy prawie adiabatycznym rozprężaniu $\mathrm{w}$ dyszy zaworu rozrządczego, w trakcie sprężania (wzrastają- cej masy gazu) w cylindrze rośnie ciśnienie i temperatura powietrza w nim zgromadzonego.

Napełniając np. cylinder hamulcowy ze zbiornika pomocniczego do wyrównania się ciśnień poprzez zawór rozrządczy z czasem napełniania 4s przy temperaturze otoczenia $19^{\circ} \mathrm{C}$ i krótkich przewodach łączących, skrajne temperatury osiagną wartość: $\mathrm{w}$ zbiorniku pomocniczym ok. $9{ }^{0} \mathrm{C}$, a w cylindrze ok. $54{ }^{0} \mathrm{C}$ i wyrównają się po czasie kilkudziesięciu sekund. W czasie wyrównywania się temperatur ciśnienia będa się zmieniały ( $\mathrm{w}$ cylindrze o ok. 0,5 bar) i w zależności od budowy zaworu i jego histerezy mogą się wyrównać przez nie w pełni domknięty zaworek napełniający.

Zakładając przemianę izotermiczną ciśnienie w cylindrze będzie się zmieniało nieco wolniej, niż przy rzeczywistej przemianie, ale końcowy bilans masy gazu po wyrównaniu się ciśnień będzie prawidłowy; w modelach i obliczeniach uproszczonych może on być stosowany.

Modelowanie procesów cieplnych utrudnione jest często tym, że brak jest wystarczających informacji liczbowych o parametrach układu, intuicyjne określenie typu przemiany w zbiorniku obarczone jest pewnym błędem. Opisywane zjawiska są zmienne w czasie, o parametrach wymiany ciepła trudnych do dokładniejszego opisu. Istnieje kilka uproszczonych metod opisu tych przemian:

- w zbiornikach mniejszych i wolnym napełnianiu (lub opróżnianiu) jako przemianę izotermiczną

- w komorach o szybkim napełnianiu jako przemiane adiabatyczną (gdy nie jest interesujące dokładne ciśnienie po końcu procesu napełniania lub gdy istnieje możliwość dopełniania zbiornika)

- uwzględnienie zależności na wymianę ciepła przy założeniu nieskończonej pojemności cieplnej ścianek zbiornika

- dodatkowe uwzględnienie osobno pojemności cieplnej zbiornika i osobno wymiany ciepła pomiędzy zbiornikiem, a otoczeniem.

Wyszczególnione rodzaje elementów zamodelowano w metodzie symulacyjnej BLOK [6]. Założono w nich brak deformacji objętościowej, gdyż stalowe ścianki zbiorników i sztywne węże hamulcowe pozwalają na przyjęcie tego założenia.

Poniżej przedstawiono skróconą analizę zjawisk termodynamicznych przy przepływie między dwoma zbiornikami. Cylinder hamulcowy można również potraktować chwilowo jako zbiornik, co nie zmienia wyniku rozważań, a upraszcza opis.

Analiza składa się $\mathrm{z}$ opisu procesu termodynamicznego zachodzącego w:

- zbiorniku opróżnianym

- elemencie dławiącym przepływ

- zbiorniku napełnianym.

Schemat analizowanego układu przedstawia rys. 2 . W zbiorniku 1 znajduje się powietrze o większym ciśnieniu niż w zbiorniku 2. Zawór otwierany jest $\mathrm{w}$ 
chwili $t_{1}$, a zamykany w chwili $t_{2}$.

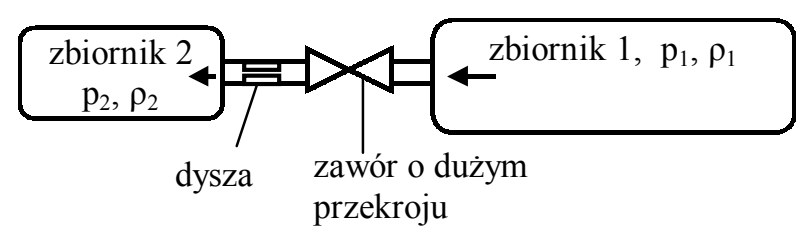

Rys. 2. Schemat układu dwóch zbiorników

Rozwiązanie zagadnienia termodynamicznego wymaga rozwiązania równań zachowania masy, pędu i energii.

Obydwa zbiorniki ze względu na procesy termodynamiczne w nich zachodzące można potraktować jako niestacjonarne układy otwarte.

Aby wyeliminować równania pędu przy analizie przemian $\mathrm{w}$ zbiornikach, dobrano tak osłony bilansowe (wewnątrz których analizuje się procesy termodynamiczne) obejmujące wnętrze zbiornika, aby wypływający lub wpływający gaz przenikał je z pomijalnie małą prędkością, a przyrost prędkości gazu i jego wyhamowanie następowało wewnątrz osłony bilansowej elementu przepływowego. Gaz przenika osłonę bilansową $\mathrm{z}$ ciśnieniem równym ciśnieniu $\mathrm{w}$ zbiorni$\mathrm{ku}$. Sytuację przedstawiono schematycznie na rys. 3, przyjmując oznaczenia:

$\mathrm{S}$ - osłona bilansowa (równa wnętrzu zbiornika),

V -objętość wewnątrz osłony bilansowej (zbiorni$\mathrm{ka}$,

$Q$ - strumień ciepła przepływający przez osłonę bilansową,

$\mathrm{m}$ - masa gazu w zbiorniku,

$\mathrm{m}_{\mathrm{w}}-$ masa gazu wypływająca ze zbiornika,

$\mathrm{p}, \rho, \mathrm{T}-$ ciśnienie, gęstość i temperatura gazu w zbiorniku.

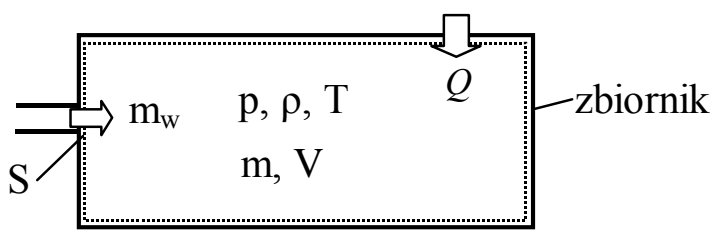

Rys. 3. Schemat wyboru osłony bilansowej

Równanie energii układu otwartego można wyrazić w ogólnej postaci na postawie [7]:

$$
E_{d}=\Delta E_{u}+E_{w y}
$$

gdzie:

$E_{d}$ - energia doprowadzona do układu,

$\Delta E_{u}$ - zmiana energii układu,

$E_{w y}$ - energia wyprowadzona z układu.

Wprowadzono założenia uściślające przedstawianą metodę:

1. gaz jest doskonały i ściśliwy,

2. zbiornik jest sztywny,

3. istnieje wymiana ciepła $\mathrm{z}$ otoczeniem (ścianami zbiornika), 4.brak jest $\mathrm{w}$ układzie wymiany pracy mechanicznej,

5.energia kinetyczna wewnątrz osłony bilansowej z powodu nieruchomości układu i pomijalnej prędkości jest pomijana,

6.pomija się energię potencjalną $\mathrm{w}$ zbiorniku oraz zmienność parametrów na przekroju lub w objętości.

Dla objętości zamkniętej osłoną bilansową, równą wewnętrznej powierzchni ścianek zbiornika, z równania zachowania masy wynika zależność:

$$
d m=d m_{w}
$$

gdzie:

$$
\begin{gathered}
d m \text { - zmiana masy powietrza wewnątrz osłony } \\
\text { bilansowej, } \\
d m_{w}-\text { przepływająca przez osłonę bilansową } \\
\text { masa (wymiany) powietrza, } \\
w-\begin{array}{c}
\text { indeks wymiany wszystkich mas przez } \\
\text { osłonę bilansową, }
\end{array}
\end{gathered}
$$

lub zapisana $\mathrm{W}$ postaci wydatku masowego $\mathrm{w}$ funkcji czasu powyższych mas:

$$
\dot{m}=\dot{m}_{w}
$$

Oznaczając indeksem „w” sumę wszystkich strumieni wymiany masy poprzez osłonę bilansową objętości:

$$
\dot{m}_{w}=\iint_{S} \rho_{w} \cdot v_{w} \cdot d S
$$

na podstawie [8] otrzymuje się równanie energii $\mathrm{w}$ postaci:

$$
\begin{aligned}
\frac{d Q}{d t}= & -\left[e_{k w}+u_{w}+\frac{1}{\rho_{w}} p_{w}\right] \dot{m}_{w}+\frac{\partial}{\partial t}[u \rho] \cdot V \\
\text { gdzie: } & \\
& e_{k} \text { - energia kinetyczna, } \\
& u \text { - energia wewnętrzna, } \\
& p-\text { ciśnienie gazu, } \\
& \rho \text { - gestość gazu, } \\
& V-\text { objętość zbiornika, } \\
& t-\text { czas. }
\end{aligned}
$$

Bez indeksu oznaczone są parametry gazu $\mathrm{w}$ osłonie bilansowej.

Wykorzystuje się równania Gibbsa:

$$
i=u+\frac{p}{\rho}
$$

oraz

$$
i_{c}=i+\frac{v^{2}}{2}
$$

gdzie:

$\mathrm{i}$ - entalpia gazu,

$\mathrm{i}_{\mathrm{c}}$ - entalpia całkowita,

$v$ - prędkość gazu.

Po przeniesieniu stronami w uproszczonym zapisie w postaci różniczkowej otrzyma się:

$$
d u=\dot{m}_{w} \cdot i_{c w} \cdot d t+d Q
$$


Dla gazu idealnego uwzględnia się:

$$
\begin{aligned}
d u & =m \cdot c_{v} \cdot d T \\
i_{w} & =c_{p} \cdot T_{w} \\
d Q & =\dot{Q} \cdot d t
\end{aligned}
$$

gdzie:

$c_{v}$ - ciepło właściwe gazu przy stałej objętości,

$c_{p}$ - ciepło właściwe gazu przy stałym ciśnieniu,

$T$ - temperatura gazu.

W opracowanym pakiecie komputerowym zapamiętywana jest gęstość i ciśnienie gazu, dlatego zależność (7) uszczegółowiono do postaci:

$$
\begin{aligned}
& m \cdot c_{v} \cdot \frac{d p}{\rho R}=\dot{Q} \cdot d t+\dot{m}_{w} \cdot\left(c_{p} \cdot \frac{p_{w}}{\rho_{w} R}+\frac{v^{2}}{2}\right) \cdot d t \\
& \text { gdzie: } \\
& \text { R- stała gazowa, }
\end{aligned}
$$

Prędkość przepływu gazu przez osłonę bilansową można pominąć. Podstawiając zależności termodynamiczne na $c_{p}$ i $c_{v}$ otrzymuje się zależność końcową:

$$
m \cdot \frac{1}{\kappa-1} \cdot \frac{d p}{\rho}=\dot{Q} \cdot d t+\dot{m}_{w} \cdot \frac{\kappa}{\kappa-1} \cdot \frac{p_{w}}{\rho_{w}} \cdot d t
$$

gdzie: $\kappa$ - wykładnik izentropy.

Równania powyższe są podstawą utworzonych $\mathrm{w}$ pakiecie wariantów szczególnych przypadków układów otwartych.

Strumień i energia doprowadzone i wyprowadzone z układu mogą być sumą kilku strumieni o różnych parametrach gazu; w przypadku strumieni wylotowych znaki wydatku masowego i entalpii są ujemne.

W trakcie opróżniania zbiornika zachodzi spadek temperatury zarówno gazu pozostającego $\mathrm{w}$ zbiorniku, jak i z niego wypływającego. Już w trakcie opróżniania zbiornika, oraz po jego ewentualnym ustaniu, zachodzi wymiana ciepła między gazem w zbiorniku, a jego ściankami. Dla normalnych zbiorników hamulcowych masa zbiornika jest wielokrotnie większa niż masa gazu, więc spadek temperatury zbiornika będzie nieznaczny i można go pominąć (przyjąć stałą temperaturę równą temperaturze $T_{0}$ otoczenia). Założono, że wymiana ciepła między gazem $\mathrm{w}$ zbiorniku a otoczeniem (osłony bilansowej) jest wprost proporcjonalna do różnicy temperatur gazu $\mathrm{w}$ zbiorniku i otoczenia. Wtedy zależność (11) przyjmuje postać

$$
\begin{aligned}
& m \cdot c_{v} \cdot \frac{d p}{\rho R}=c \cdot\left(T-T_{0}\right) \cdot d t+\dot{m}_{w} \cdot i_{w} \cdot d t \\
& \text { gdzie: }
\end{aligned}
$$

$c$ - współczynnik przewodności cieplnej ścianek zbiornika,

$T$-aktualna temperatura gazu,

$T_{0}$ - temperatura otoczenia zadana $\mathrm{w}$ symulacji.

$\mathrm{W}$ modelu tym równania przyjmują ostateczną postać:

$$
\dot{\rho}=m / V
$$

$$
\begin{gathered}
\dot{p}=\frac{(\kappa-1)}{V} \cdot(\dot{q}+\dot{E}) \\
\dot{q}=c \cdot\left(T-T_{0}\right)
\end{gathered}
$$

Inaczej przedstawia się proces termodynamiczny zachodzący w zbiorniku dopełnianym.

Zależność (11) dla zbiornika dopełnianego nie może zostać uproszczona w sposób, jaki wykorzystano dla zbiornika opróżnianego, bo strumień gazu doprowadzanego do zbiornika ma zwykle inną temperaturę, niż gaz w zbiorniku. Prowadząc osłonę bilansową podobnie, jak dla zbiornika opróżnianego, gaz doprowadzany do zbiornika przekraczając osłonę bilansowa osiaga stan stagnacji i jego ciśnienie jest równe ciśnieniu gazu wewnątrz osłony bilansowej.

Poprzez omawianą osłonę bilansową przepływa strumień masy $\dot{m}_{w}$ o ciśnieniu $p_{w}=p$, ale $\rho_{w} \neq \rho$.

Zależność (11) można wyrazić w postaci:

$$
m \cdot c_{v} \cdot \frac{d p}{\rho R}=\dot{Q} \cdot d t+\dot{m}_{w} \cdot i_{w} \cdot d t
$$

Entalpia strumienia $i_{w}$ wynika ze zjawisk zachodzących w elemencie dławiącym przepływ, łączącym oba analizowane zbiorniki.

W przypadku zbiornika z przemianą adiabatyczną zanika strumień ciepła $\dot{Q}$.

\subsection{Zbiornik $\mathrm{z}$ adiabatyczną przemianą gazu}

Jest to pojemność bez wymiany ciepła pomiędzy zgromadzonym $\mathrm{w}$ zbiorniku gazem a jego ściankami (przemiana adiabatyczna). Gaz przepływający przez osłonę bilansową na zewnątrz posiada takie same parametry, jak gaz znajdujący się w zbiorniku:

$$
p_{w}=p, \rho_{w}=\rho
$$

i równanie (13) dla przemiany adiabatycznej upraszcza się do postaci:

$$
m \cdot c_{v} \cdot \frac{d p}{\rho R}=\dot{m}_{w} \cdot\left(c_{p} \cdot \frac{p}{\rho R}\right) \cdot d t
$$

Wprowadza się przekształcenia:

$$
\begin{gathered}
m \cdot \frac{d p}{\rho}=\dot{m}_{w} \cdot \kappa \cdot \frac{p}{\rho} \cdot d t \\
d m=\dot{m}_{w} \cdot d t
\end{gathered}
$$

oraz dla stałej objętości

$$
\frac{d m}{m}=\frac{d \rho}{\rho} .
$$

Po powyższych przekształceniach i scałkowaniu z zależności (19) otrzymuje się równanie izentropy:

$$
\frac{p}{\rho^{\kappa}}=\text { const }
$$

Tak więc $\mathrm{w}$ trakcie opróżniania zbiornika $\mathrm{z}$ przemianą adiabatyczną gazu, jak należało się spodziewać, zachodzi rozprężanie izentropowe i stopniowy spadek temperatury gazu. 


\subsection{Zbiornik $\mathrm{z}$ izotermiczną przemianą gazu}

Jest to zbiornik z idealną wymianą ciepła pomiędzy zgromadzonym $\mathrm{w}$ nim gazem a jego ściankami (i otoczeniem) dając przemianę izotermiczną. Zmiany parametrów gazu $\mathrm{w}$ zbiorniku dla izotermicznej przemiany zostały opisane zależnością:

$$
\begin{gathered}
\dot{\rho}=\dot{m} / V \\
\dot{p}=R \cdot T_{0} \cdot \dot{m} / V
\end{gathered}
$$

$\mathrm{W}$ przemianie izotermicznej gaz zachowuje stała temperature a całe dodatkowe ciepło gazu w zbiorniku zostaje odprowadzone przez ścianki zbiornika.

\subsection{Zależności teoretyczne przeplywu powietrza przez element lączący oba zbiorniki}

Oba analizowane zbiorniki połączone są zaworem, otwierającym i zamykającym w sposób natychmiastowy przelot oraz elementem dławiącym (dyszą) limitującym strumień powietrza. Elementem dławiącym może być również sam zawór i wtedy jest analizowany stan jego otwarcia. Przepływ rzeczywisty w dyszy lub zaworze można $\mathrm{z}$ dobrym przybliżeniem opisać zależnościami na przepływ izentropowy, wprowadzając dodatkowo łączny współczynnik kontrakcji i oporów $\mu$ i obliczyć strumień masy wg zależności:

$$
\dot{m}=\mu \cdot \dot{m}_{t}
$$

Dla przepływu izentropowego strumień masy określony jest wzorem:

$$
\begin{aligned}
& \dot{m}_{t}=A \cdot \sqrt{p_{1} \cdot \rho_{1}} \cdot \sqrt{\frac{2 \kappa}{\kappa-1}} \cdot \sqrt{\left(\frac{p_{2}}{p_{1}}\right)^{\frac{2}{\kappa}}-\left(\frac{p_{2}}{p_{1}}\right)^{\frac{\kappa+1}{\kappa}}}= \\
& =A\left(\frac{p_{2}}{p_{1}}\right)^{\frac{1}{\kappa}} \sqrt{\frac{2 \kappa}{\kappa-1} R T_{1}\left[1-\left(\frac{p_{2}}{p_{1}}\right)^{\frac{\kappa-1}{\kappa}}\right]}
\end{aligned}
$$

gdzie:

1 - indeks wlotu do dyszy,

2 - indeks wylotu z dyszy,

$p_{1}, \rho_{l}, T_{1}$ - chwilowe parametry gazu w stanie stagnacji na wylocie ze zbiornika opróżnianego,

$p_{2}$ - chwilowe parametry gazu $\mathrm{w}$ stanie stagnacji na wlocie do zbiornika dopelnianego,

$A$ - pole najwęższego przekroju dyszy lub zaworu.

Maksymalny teoretyczny strumień masy, przy danych chwilowych parametrach poczattkowych $p_{l}, \rho_{I}$, $T_{l}$, wystapi, jeśli w przekroju wylotowym dyszy panować będa parametry krytyczne, to znaczy prędkość przepływu jest w nim równa prędkości dźwięku:

$$
\dot{m}_{\max t}=A \sqrt{\kappa p_{1} \rho_{1}}\left(\frac{2}{\kappa+1}\right)^{\frac{\kappa+1}{2(\kappa-1)}}
$$

Krytyczny stosunek ciśnień wynosi wtedy:

$$
\beta_{k r 1}=\left(\frac{p_{2}}{p_{1}}\right)_{\max }=\frac{p_{k r}}{p_{1}}=\left(\frac{2}{\kappa+1}\right)^{\frac{\kappa}{\kappa-1}}
$$

Ponieważ osłony bilansowe przyjęto $\mathrm{w}$ miejscach stagnacji gazu, energię strumienia na wlocie do dyszy można wyrazić w funkcji parametrów gazu w zbiorniku opróżnianym:

$$
\dot{E}_{1}=\dot{m}_{w} \cdot i_{w}=\dot{m} \cdot c_{p} \cdot T=\dot{m} \cdot \frac{\kappa}{\kappa-1} \cdot \frac{p_{1}}{\rho_{1}}
$$

$Z$ zasady zachowania energii elementu przepływowego wynika dla zbiornika dopełnianego:

$$
i_{w 2}=i_{w 1}
$$

gdzie:

$i_{w l}$ - entalpia gazu wylotowego ze zbiornika opróżnianego,

$i_{w 2}$ - entalpia gazu wlotowego do zbiornika napełnianego.

W dyszy cylindrycznej posiadającej ostre krawędzie najniższe ciśnienie występuje na wylocie dyszy, gdzie gaz posiada określona prędkość i energię kinetyczną. Energia ta wytracana jest na mieszanie i zamieniana na ciepło pozostające $\mathrm{w}$ gazie, powodując wzrost temperatury gazu wlotowego do zbiornika; zależność (31) jest ciagle zachowana.

W rzeczywistej dyszy, jak i w zaworze przebieg strumienia masy $\mathrm{w}$ zależności od stosunku ciśnień $\mathrm{p}_{2} / \mathrm{p}_{1}$ przebiega inaczej niż $\mathrm{w}$ dyszy izentropowej, a stosunek krytyczny ciśnień $\beta$, dla którego uzyskuje się strumień maksymalny przyjmuje wartości niższe, niż teoretyczny; oznaczono go przez $\beta_{\mathrm{kr} 2}$. Zależności wykorzystywane $\mathrm{w}$ tym przypadku przedstawiono $\mathrm{w}$ [6] dla dyszy uogólnionej adiabatycznej. Analiza wyników pomiarów na elementach aparatury hamulcowej potwierdziła zgodne $\mathrm{z}$ literaturą występowanie przesunięcia punktu krytycznego przepływu. Osiagga on wartości ok. $0,3 \div 0,5$.

\subsection{Uproszczenie równań przepływu}

Ze względu na trudność uzyskania jednoznacznych parametrów przesuniętego punktu krytycznego, wystarczające jest zastosowanie uproszczonych zależności przepływowych. Wykorzystano zależności zaproponowane przez Bendemanna, a zaprezentowane $\mathrm{w}$ [8].

Maksymalny rzeczywisty strumień masy przepływającej przez rzeczywisty otwór dla stosunku ciśnień $\mathrm{p}_{2} / \mathrm{p}_{1}<\beta$ ' można wyliczyć ze wzoru:

$$
\dot{m}_{\max }=A \mu \sqrt{\kappa p_{1} \rho_{1}}\left(\frac{2}{\kappa+1}\right)^{\frac{\kappa+1}{2(\kappa-1)}}
$$

W zakresie $\mathrm{p}_{2} / \mathrm{p}_{1}>\beta$ ' charakterystykę przelotowości można opisać $\mathrm{z}$ małym błędem elipsą:

$$
\left(\frac{\dot{m}}{\dot{m}_{\max }}\right)^{2}+\frac{\left(\frac{p_{2}}{p_{1}}-\beta^{\prime}\right)^{2}}{\left(1-\beta^{\prime}\right)^{2}}=1
$$




$$
\begin{gathered}
\text { Ostatecznie dla } \mathrm{p}_{2} / \mathrm{p}_{1}>\beta^{\prime}: \\
\dot{m}=A \mu \sqrt{\kappa p_{1} \rho_{1}}\left(\frac{2}{\kappa+1}\right)^{\frac{\kappa+1}{2(\kappa-1)}} \cdot \sqrt{1-\left(\frac{\left(p_{2} / p_{1}\right)-\beta^{\prime}}{1-\beta^{\prime}}\right)^{2}}
\end{gathered}
$$

Porównując zależności teoretyczne dla przepływu izentropowego i uproszczenia eliptycznego stwierdzono, że względny błąd w całym zakresie przepływów nie był większy niż $0,3 \%$, co jest wystarczające dla analiz przepływu przez dysze w zaworze rozrządczym i przyspiesza nieco proces symulacyjny.

\subsection{Przepływy przez elementy szeregowe}

Strumień przepływu może być również ograniczany wymiarami i kształtem kanałów dolotowych. W takim przypadku symulacja jest utrudniona, gdyż zależności na masowe natężenie przepływu zależą od całego przebiegu kanałów powietrznych, są silnie nieliniowe i zależne od pojawienia się przepływu krytycznego w którymś $\mathrm{z}$ elementów przepływowych. Istnieje kilka sposobów modelowania takiego układu.

- Rozwiązaniem stosowanym przez autora jest wykorzystanie procedury KASKADA [6]. Określa ona masowe natężenie przepływu przez kaskadę (szereg) elementów dławiących przepływ o pomijalnej objętości. Założono w niej przepływ adiabatyczny. Posiada ona jednak ograniczoną dokładność ze względu na przyjęty model (brak wymiany ciepła).

- Innym rozwiązaniem jest uwzględnienie w modelu dodatkowych niewielkich pojemności pomiędzy poszczególnymi odcinkami kanału i określanie ich stanu. Pozwala to na uzyskanie znacznej dokładności modelu przepływu, jednakże wadą jest samo istnienie tych pojemności, które moga nieco zmienić bilans masy w układzie. Z kolei zamodelowanie bardzo małych pojemności wymaga znacznego zmniejszenia kroku obliczeń, aby nie otrzymać niestabilności numerycznej układu.

\subsection{Dysza uogólniona $z$ wymianą ciepła $z$ otocze- niem}

Doświadczenia wykonywane na różnych rodzajach hamulcowej aparatury pneumatycznej wykazały pewne rozbieżności pomiędzy wynikami metody symulacyjnej, zakładającej przepływ adiabatyczny w dyszy, a wynikami pomiaru. W trakcie przepływu powietrza występuje zmiana temperatury zewnętrznej zaworów oraz innych elementów łączących, przez które napełniano dany zbiornik. Oznacza to, że założenie o adiabatyczności przepływu w elemencie dławiącym nie jest (w analizowanych przypadkach) właściwe. Gaz rozprężając się w zaworze oziębia się i jak się w trakcie eksperymentu okazało, oziębia w zauważalnej mierze korpus zaworu. Jednocześnie jednak następują straty energii kinetycznej strumienia w całym przewodzie łączącym oba zbiorniki zamieniane na ciepło $\mathrm{i}$ podwyższające temperaturę gazu. Powietrze w trakcie rozprężania w zaworze, ochładzając zawór, zyskuje ciepło od korpusu zaworu, otoczenia i ewentualnie od elementów złącz pneumatycznych na drodze gazu do zbiornika. Gaz na wlocie do zbiornika napełnianego posiada więc inną temperaturę $\mathrm{i}$ dalsza wymiana ciepła w zbiorniku jest inna, niż wynika to $\mathrm{z}$ modelu adiabatycznego dyszy. Zjawisko powyższe uwzględniono w pakiecie BLOK [4] w sposób uproszczony.

Założono, że zależności na masowe natężenie przepływu są identyczne, jak dla dyszy uogólnionej adiabatycznej. Zależność na strumień energii na wylocie przyjmuje natomiast postać:

$$
\dot{i}_{w y}=\dot{i}_{w} \cdot(1-\text { wspstr })
$$

gdzie:

wspstr - współczynnik straty entalpii na zaworze, teoretycznie może on być dodatni lub ujemny,

$i_{w} \quad$ - entalpia gazu wypływającego ze zbiornika równa jest zależności (31),

$i_{w y}$ - entalpia gazu wpływającego do zbiornika o niższym ciśnieniu.

Różnica entalpii wpływającej i wypływającej nie jest bilansowana w układzie.

\subsection{Cylinder hamulcowy}

Sposób modelowania cylindra hamulcowego w różnych wersjach przedstawiono w [6]. Wybór wersji zależy od wymaganej dokładności modelu, ale i również od możliwości identyfikacji parametrów modelu. Model prostszy jest modelem izotermicznym, bardziej rozbudowany model jest nazwany CYLU, choć w nim wprowadzono również uproszczenia, np. pominięto masowe siły bezwładności, gdyż w układzie hamulcowym o stosunkowo małych prędkościach ruchu tłoka, ale znacznych siłach w nim występujących, nie są one istotnym zagadnieniem. W modelu tym zamodelowano również wymianę ciepłą $\mathrm{z}$ otoczeniem zakładając, że ścianki cylindra mają temperaturę otoczenia, tarcie tłoka o ścianki cylindra i sprężystość układu po nominalnym wyczerpaniu się skoku tłoka. Model można rozszerzyć o inne elementy pakietu BLOK.

Modele cylindra ( o schemacie przedstawionym na rys. 4) posiadają trzy zakresy pracy podane w [6].

Zakres 1. Dla małych ciśnień tłok znajduje się w skrajnym położeniu minimalnej objętości, wymuszonym dociskiem sprężyny i ogranicznikiem ruchu. Objętość ta składa się $\mathrm{z}$ objętości resztkowej cylindra i pojemności przewodu dolotowego.

Zakres 2. Przy stosunkowo małym ciśnieniu w cylindrze następuje ruch tłoka, którego położenie wynika $\mathrm{z}$ równowagi ciśnień, a pośrednio $\mathrm{z}$ masy gazu wpływającej do cylindra.

Zakres 3. Przy większych ciśnieniach tłok osiaga w przybliżeniu maksymalne wychylenie; zakłada się w tym zakresie niewielkie dodatkowe ugięcia tłoka.

Tarcie występujące w uszczelnieniach elementów ruchomych zaworu może w zauważalny sposób zmienić działanie układu mechanicznego. Dla smarowanych elementów gumowych posiada ono nie w pełni 
określoną charakterystykę, będąca połączeniem tarcia suchego i wiskotycznego. Z wystarczająca dokładnością można ją przyjąć jako tarcie Coulomba z szeregową podatnością $i$ thumieniem wiskotycznym; przedstawiono je $\mathrm{w}$ [5] i zaimplementowano je w pakiecie BLOK [6]. Model tarcia zaprojektowano tak, aby cechował się dużą odpornością na niestabilność numeryczną. Tarcie tłoka o ścianki cylindra zmieniać się może $\mathrm{w}$ dużych granicach $\mathrm{z}$ powodu różnych warunków smarowania. Uszczelnienie jest typu wargowego i tarcie zmienia się także ze zmianą ciśnienia Przykładowo amplitudy siły tarcia występującej między tłokiem a cylindrem, przeliczone na ciśnienie $\mathrm{w}$ cylindrze, dla ciśnienia 3,8 bar w cylindrze o średnicy 14" ze świeżym rzadkim smarem osiagają wartość ok. 0,175 bar.

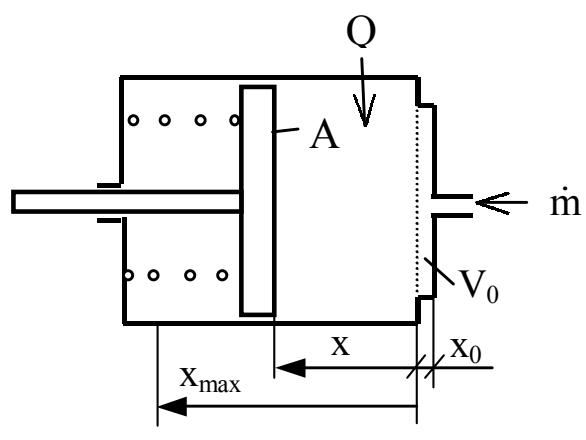

Rys. 4. Schemat cylindra uogólnionego

\subsection{Dynamika układu mechanicznego.}

Stosunkowo duże powierzchnie membran i siły w sprężynach $\mathrm{w}$ porównaniu $\mathrm{z}$ masami elementów ruchomych powodują, że pominięcie sił bezwładności nie wprowadza znaczących niedokładności modelu. Położenie elementu ruchomego łatwo określić $\mathrm{z}$ równania dynamiki jego ruchu. Przy małej masie elementu konieczne jest jednak stosowanie bardzo małych kroków dla rozwiązania różniczkowych równań ruchu, aby nie uzyskać niestabilności numerycznej ruchu elementu. Jednakże nie jest to stan ułatwiający modelowanie. Przydatne może być zastosowanie sztucznie zawyżonej (nawet kilkakrotnie) masy elementu oraz zawyżenie thumienia występującego w układzie. Niewłaściwy model tłumienia może być również powodem wzrostu niestabilności. W modelu konieczne jest stosowanie ograniczników ruchu, gdyż posiada je prawie każdy element ruchomy zaworu rozrządczego. Autor wykorzystuje model plastyczny zderzaka nieodkształcalnego ( $\mathrm{w}$ którym brak jest energii odbicia).

Dla modelowania uproszczonego można pominąc rozwiązanie równań ruchu i bazować na sterowaniu zaworami na zasadzie równowagi sił działających na elementy ruchome. Można wykorzystać metodę dokładniejszą określającą położenie elementu ruchomego, co jest numerycznie kłopotliwe, lub prostszą dwustanową: zawór otwarty -zamknięty.

\subsection{Sterowanie zaworami}

Sterowanie praca nowoczesnego zaworu rozrządczego odbywa się zaworami grzybkowymi regulowanymi układami membran. Sterowania suwakowego obecnie nie stosuje się. Dobór sztywności sprężyn w układzie i małe tarcie powodują, że w większości przypadków można zawory traktować jako układy dwustanowe, pomijając w symulacji proces domykania się grzybków zaworków. Jednakże przy dokładniejszym modelowaniu $\mathrm{w}$ następujących przypadkach należy potraktować proces sterowania zaworów jako ciagly:

- gdy tworzy się dodatkowe komory pod membranami, zamykane dyszami o małym przelocie, by ciśnienie przy membranie zmieniało się wolniej i działało jako amortyzator

- gdy komora pod membrana posiada mała pojemność; wtedy ruch trzona $\mathrm{z}$ membraną wywołuje rejestrowalne zmiany ciśnienia w komorze i wywołuje również „dławienie" ruchu

- niekiedy układy są bardzo zrównoważone i wykonują niewielkie ruchy, wtedy w dłuższym czasie moga pracować na przydławionych przepływach; nieuwzględnianie tego procesu może prowadzić do niedokładności modelu.

Należy również uwzględnić $\mathrm{w}$ modelu, że powierzchnie efektywne membran różnią się od ich wymiarów konstrukcyjnych.

Niektóre zawory rozrządcze posiadają zespoły, których działanie zależne jest nie tylko od bieżącego układu ciśnień, ale i od uprzednich stanów (historii działania) zaworu. Wymaga to w modelu użycia elementu pamięci układu i elementu sterującego nim. W takim przypadku na początku symulacji należy dodatkowo zadać tę wartość lub wczytać jako warunek poczatkowy. Wprowadza to dodatkowe wymagania w metodzie rozwiązania równań układu.

\section{Przykłady modelowania zaworu rozrządczego Est3f}

Dla omawianych zagadnień modelowania przedstawiono trzy modele zaworu rozrządczego lub jego części o różnym stopniu dokładności. Dwa pierwsze mogą być analizowane samodzielnie (jako odrębny model pojedynczego układu wagonowego) lub zabudowane w modelu całopociagowym. Zabudowa zaworu w takim modelu (całopociaggowym) stanowić może pewien problem organizacyjny, gdyż zaworów rozrządczych różnych typów może być w pociągu kilkadziesiąt. Autor wykorzystuje takie uporządkowanie zmiennych i tablic, że także w zaworach o odmiennej budowie posiadają one takie same nazwy, różniąc się tylko numerem indeksu ( $\mathrm{w}$ modelach prostszych część indeksów nie jest wykorzystana). Należy nadmienić, że po utworzeniu modelu dokładniejszego, model uproszczony można pominąć. Dla kompletności wywodu przedstawiono jednak wszystkie modele. 
Jako wzór wybrano najbardziej rozpowszechniony i dobrze znany zawór H1E1 zakupiony w Polsce jako licencja zaworu Est3f firmy Oerlikon.

\subsection{Model funkcjonalny uproszczony}

Model ten został zbudowany przez autora najwcześniej i sprawdził się w różnorodnych symulacyjnych obliczeniach całopociagowych, np. $[3,4]$. Pozwala on na obliczenia symulacyjne różnorodnych procesów hamowania, odhamowania i przepełnienia zbiorników sterujących składu pociagu. Model ten z wystarczającą do analiz całopociagowych wiernością, może opisywać przy typowych analizach zawory różnych producentów(z każdorazowo innymi parametra$\mathrm{mi})$.

Model posiada następujące cechy:

- w cześci przełączającej jest to model funkcyjny, zadający dwustanowo otwarcia zaworów na podstawie zwrotów sumarycznych sił działających na grzybki zaworów

- stwierdzono, że mimo założenia uproszczenia zaworu do zadanych analiz całopociagowych, nie można aproksymować procesów napełniania zbiorników i cylindra hamulcowego zależnościami funkcyjnymi, ale określać je $\mathrm{z}$ całkowania procesów termodynamicznych w czasie

- założono procesy izotermiczne; przepływy przez dysze obliczane są zależnościami wg Bendemanna [6] i współczynnikami liczbowymi wg [2]

- działanie przyspieszacza modelowane jest zadanym, opisanym funkcją masowym natężeniem przepływu. Funkcje tę można utworzyć albo z wyników modeli dokładniejszych lub z wyników pomiarów. W prezentowanej wersji jest ona zlinearyzowana i utworzona dla pracy od nominalnego ciśnienia.

\subsection{Model funkcjonalny udokładniony}

Założeniem tego modelu było uzyskanie dużej dokładności modelowania zaworu również we wszelkich nietypowych sytuacjach bez analizy dynamiki cześsi mechanicznej układu. Tworzenie takiego modelu wymaga dokładnej analizy konstrukcji zaworu lub wręcz, o ile to możliwe, oparcia się o rysunki konstrukcyjne zaworu. Weryfikacja na stanowisku badawczym jest niezbędna $\mathrm{z}$ tego powodu, że niektóre funkcje są zależne od zjawisk termodynamicznych określanych teoretycznie z mniejszą dokładnością.

Układ zaworu wraz z elementami stanowiącymi całość modelu symulacyjnego przedstawia rys. 5, wykorzystując numerację zaworków $\mathrm{z}$ materiałów firmy BUMAR-FABLOK, a na rys. 6 przedstawiono algorytm obliczeń dla udokładnionego modelu zaworu. Liczbami rzymskimi $\mathrm{I} \div \mathrm{X}$ oznaczono numery zaworków, d1 $\div \mathrm{d} 12$ - numery dysz rzeczywistych, dham dysza napelniania cylindra, dzask - dysza zaskoku, dy $1 \div$ dy 9 - numery dysz przełączalnych $\mathrm{w}$ symulacji, s $\div$-s 9 - numery strumieni gazu, v1 $\div$ v 7 - numery objętości (odpowiadaja im ciśnienia $\mathrm{p} 1 \div \mathrm{p} 7$ i gęstości $\mathrm{r} 1 \div \mathrm{r} 7)$. Punkty ciśnienia p8 i p9 nie są związane z objętościami, atm -ciśnienie atmosferyczne, pster - ciśnienie sterowania. Objętości: PG(v0)- objętość zbiornika imitującego przewód główny, v1 - komora wspornika, v2 -zbiornik sterujący, v3 - cylinder hamulcowy, v4 - zbiornik pomocniczy, v5 $\div \mathrm{v} 7$ - komory przyspieszacza, „pamięć” - układ mechanicznopneumatyczny zapamiętujący uprzedni stan zaworka.

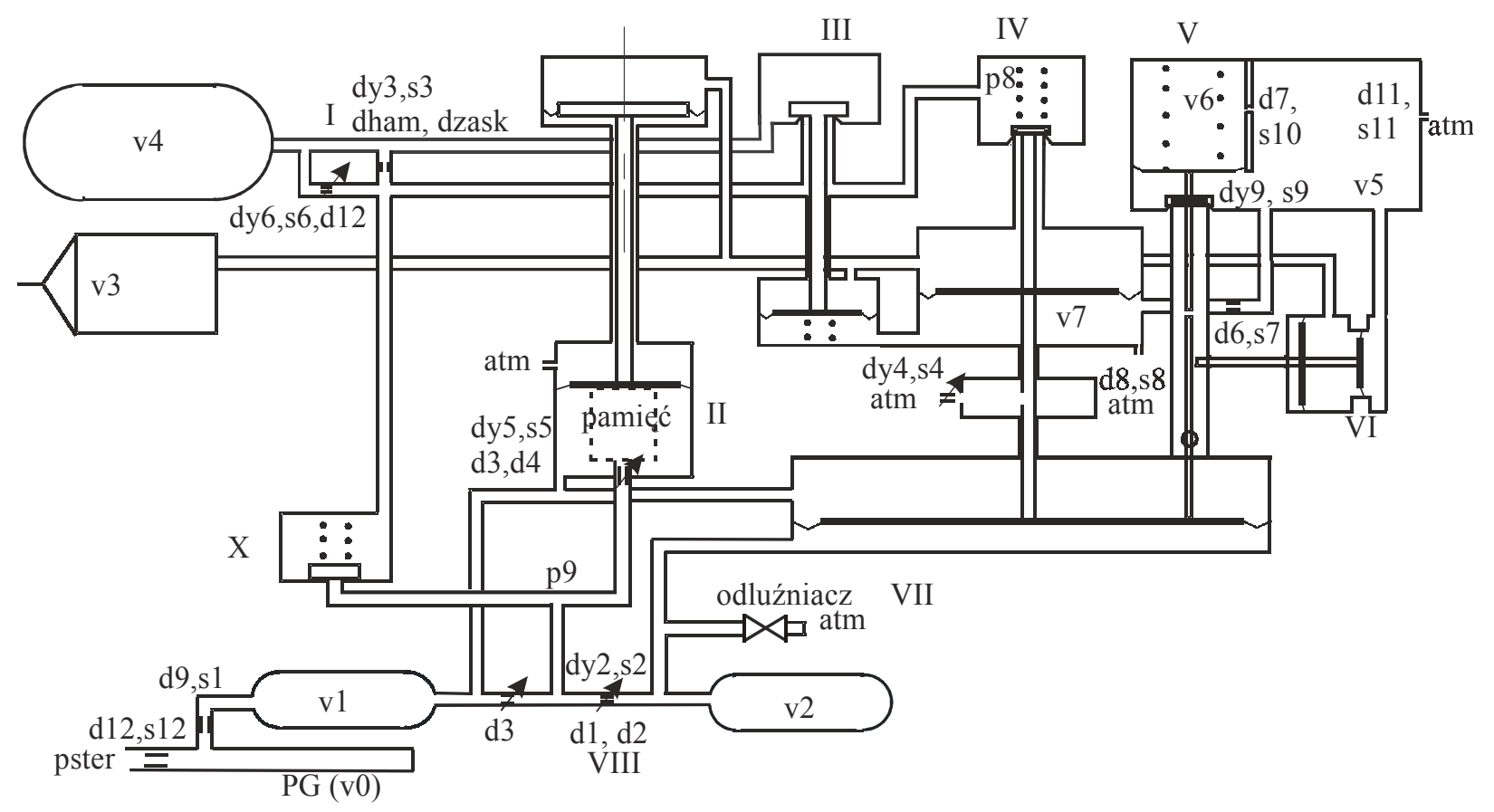

Rys. 5. Schemat modelu udokładnionego dla zaworu Est3f 


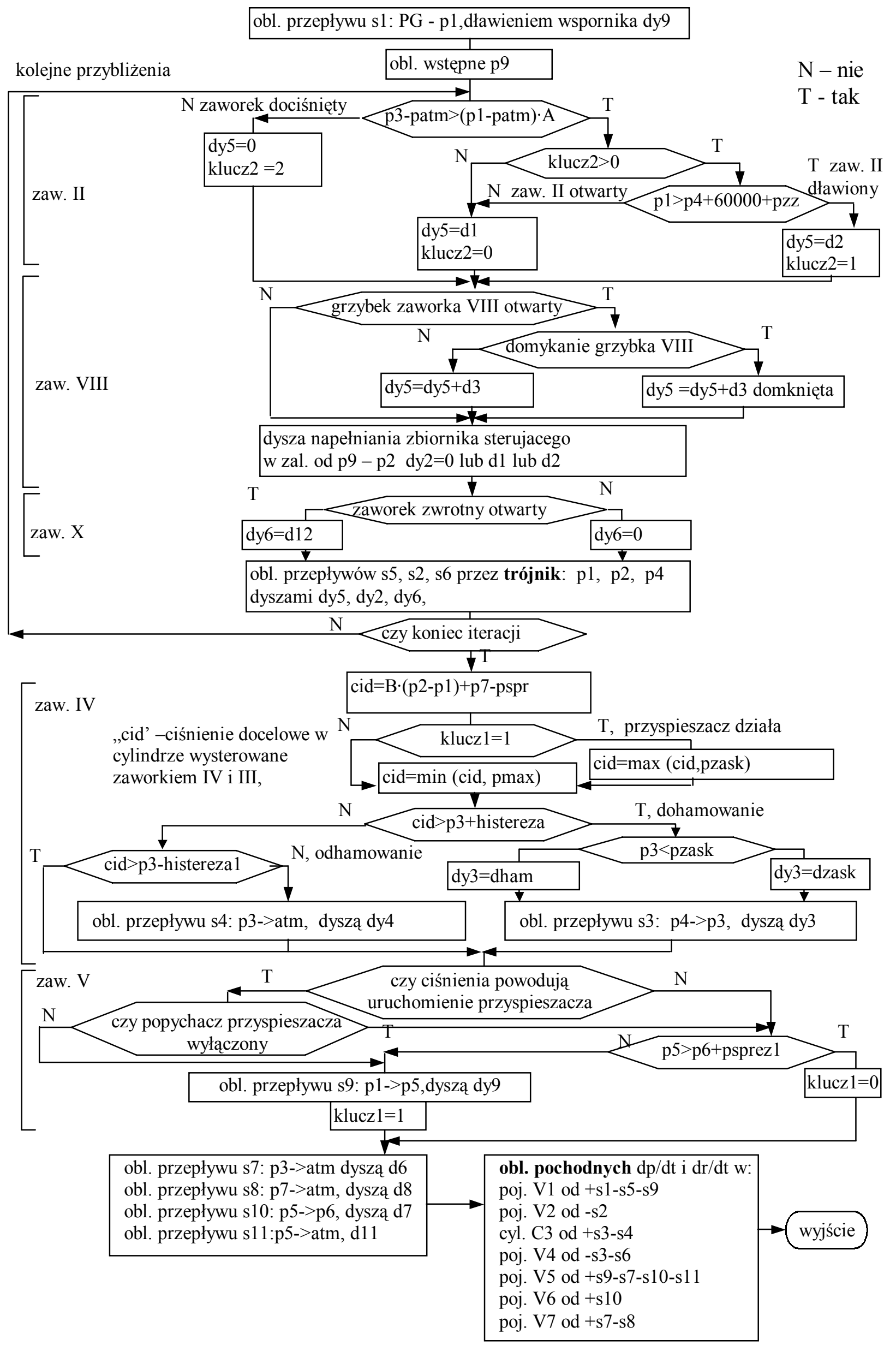

Rys. 6. Algorytm udokładnionego modelu zaworu Est3f; oznaczenia w tekście 
Zamykanie i otwieranie przelotów zaworów jest dwustanowe, oparte o sumę sił działających na trzon grzybka danego zaworu. W zaworku napełniającym uwzględniono domykanie zaworu.

Modelowanie przyspieszacza oparte jest, jak i pozostałej części zaworu, na otwieraniu grzybków, wynikające $\mathrm{z}$ równowagi sił.

Fragmentami zaworu, które wymagają szczególnej uwagi dla konkretnego zaworu są:

1. przyspieszacz, w którym $\mathrm{w}$ opisywanej metodzie nie uzyskano pełniej adekwatności z rzeczywistością (jeżeli chodzi o komory pośrednie), ale charakterystyki zewnętrzne są poprawne.

2. układ napełniania zbiornika pomocniczego (i częściowo sterującego). W zależności od układu ciśnień przepływ jest $\mathrm{w}$ różny sposób dławiony szeregowo dyszą napełniania zbiorników i dyszą napełniania cylindra (oraz oporem przewodu). Dodatkowo napełnianie zbiornika sterującego można uznać za odgałęzienie napełniania zbiornika pomocniczego od pośredniego ciśnienia p9. Istnieje kilka możliwości uwzględnienia przepływów w tym węźle:

- wprowadzenie pośredniej objętości (wymaga zmniejszenia kroku symulacyjnego i wprowadza dodatkową nierzeczywistą pojemność w układzie)

- zastosowanie przybliżonej funkcji aproksymowanej na rozkład ciśnień (metoda nie zapewnia wystarczającej dokładności dla wszystkich stanów układu)

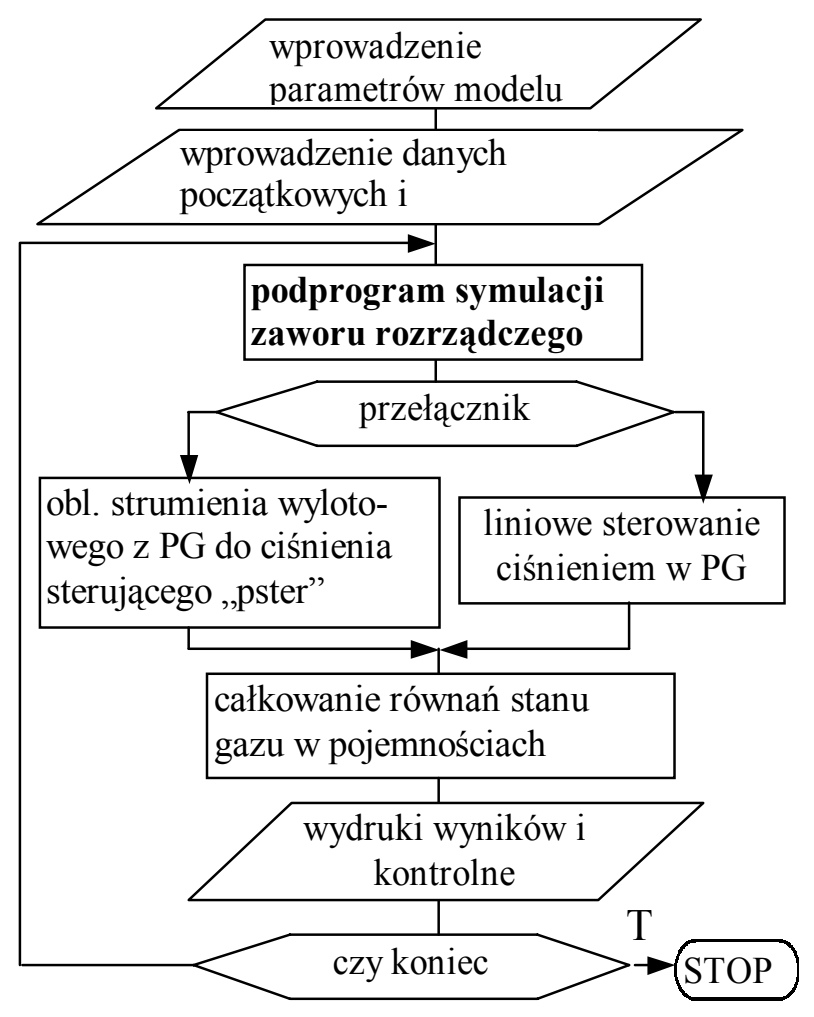

Rys. 7. Umieszczenie modelu zaworu rozrządczego w programie symulacyjnym
- zastosowanie procedury obliczenia przepływu w rozgałęzieniu. W symulacji wybrano tę metodę, wykorzystując zależności opisane $\mathrm{w}$ procedurze TROJNIK [6]. Ponieważ procedura ta wykorzystuje liniowe zależności na rozkład strumieni w trójniku, zastosowano ją z kilkukrotnym udokładnieniem wyniku metodą kolejnych przybliżeń; w każdym przybliżeniu określano na nowo otwarcia zaworów.

3. w zaworze Est3f stan otwarcia zaworka II zależy od uprzednich stanów jego działania. Jest to dodatkowa zmienna uwzględniania $\mathrm{w}$ symulacji i ustawiana na jej początku.

Model zaworu może być analizowany jako odrębny układ symulacyjny w sposób przedstawiony na rys. 7 . Sterowanie ciśnieniem w przewodzie głównym może odbywać się na dwa sposoby: jako liniowa zadana funkcja ciśnienia lub PG traktowany jest jako zbiornik połączony z ciśnieniem sterowania poprzez dyszę.

\subsection{Model szczególowy}

Model szczegółowy opracowano dla części zaworu związanej z zespołem przyspieszacza i napełniania cylindra. Jego celem było możliwie maksymalne zbliżenie modelu do części układu rzeczywistego.

Model utworzono w oparciu o pakiet BLOK [6]. Poszczególne części zaworu zostały zamodelowane jako dyskretne elementy pneumatyczne lub mechaniczne, wybrane $\mathrm{z}$ palety dostępnych elementów. Ich wzajemne powiązania oraz parametry liczbowe dane są w zadanym pliku sterującym. Na rys. 8 przedstawiono utworzoną na ich podstawie konfigurację ukła$\mathrm{du} ; \mathrm{w}$ ramkach wymieniono wykorzystane procedury pakietu BLOK [6]. W prawej górnej ramce niektóre nazwy procedur uzupełniono zakończeniami wyjaśniającymi ich znaczenie.

W modelu uwzględniono dynamikę elementów mechanicznych, zmianę przekroju zaworu przy jego domykaniu i zmianę objętości komory na skutek deformacji membrany. Parametry modelu oparto na danych konstrukcyjnych. Aby nie komplikować nadmiernie budowy modelu, niekrytyczne dla danej chwili procesu wyłączenie przelotu dyszą nr 10 i wyłączenie zblokowania ruchu mas (odchylna dźwignia popychacza przyspieszacza) modelowano zmiennym przekrojem 2 dyszy 10 i zmiennym przekrojem 1 zaworu 1 zadanych na podstawie wyników wstępnej symulacji; pozwoliło to na znaczną redukcją modelu.

Powyższą metodą nie zamodelowano całego zaworu, gdyż wydaje się, że poza działaniem przyspieszacza, wystarczającą dokładność posiada model udokładniony opisany w rozdziale 5.2. 


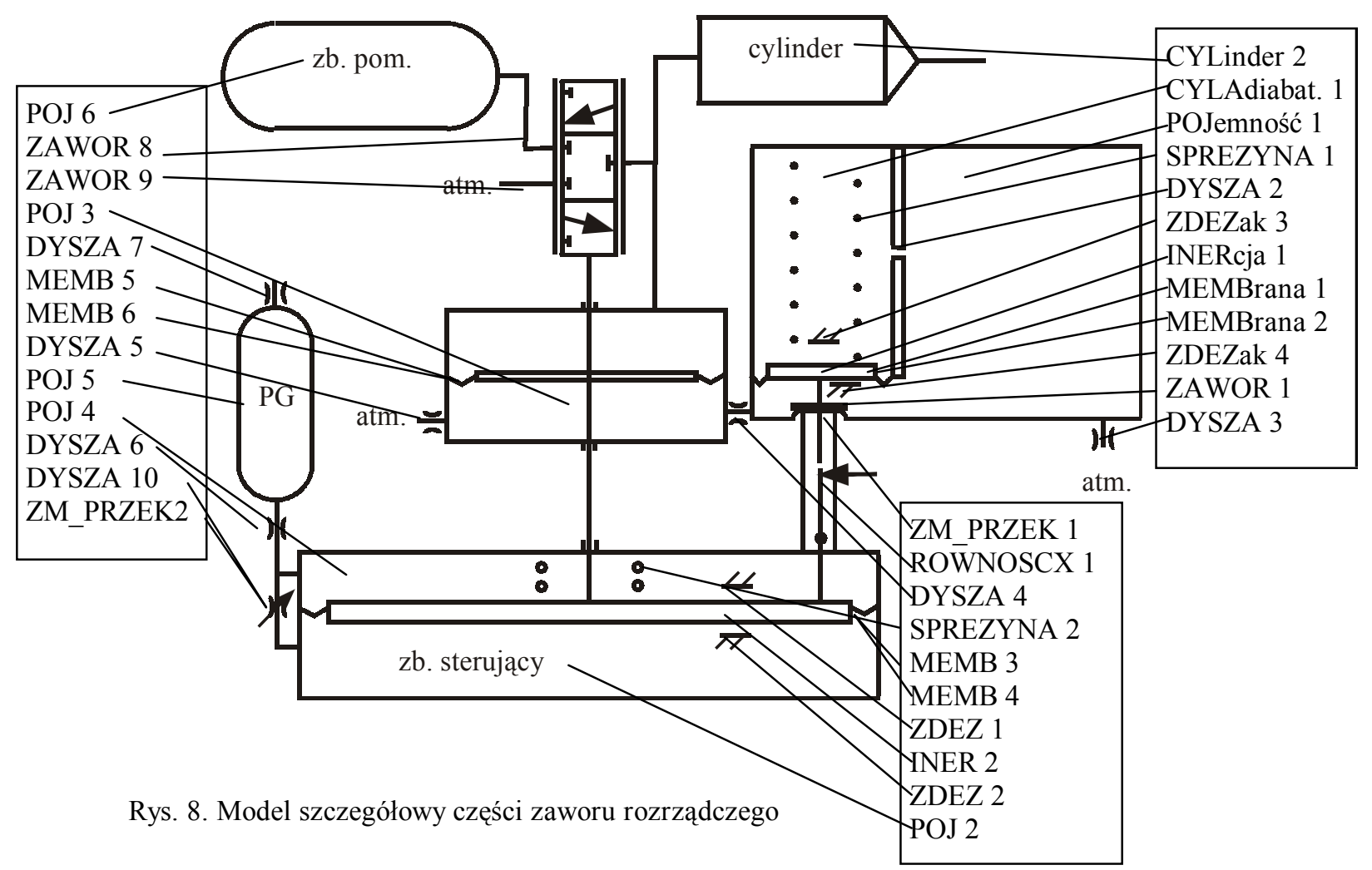

\subsection{Porównanie wyników pomiarów i symulacji}

Dla porównania $\mathrm{z}$ wynikami symulacji dokonano różnorodnych pomiarów rzeczywistego zaworu na stanowisku badawczym. Oprócz standardowych pomiarów ciśnienia na wyjściach zaworu, dodatkowo mierzono je w komorach wewnętrznych zaworu i

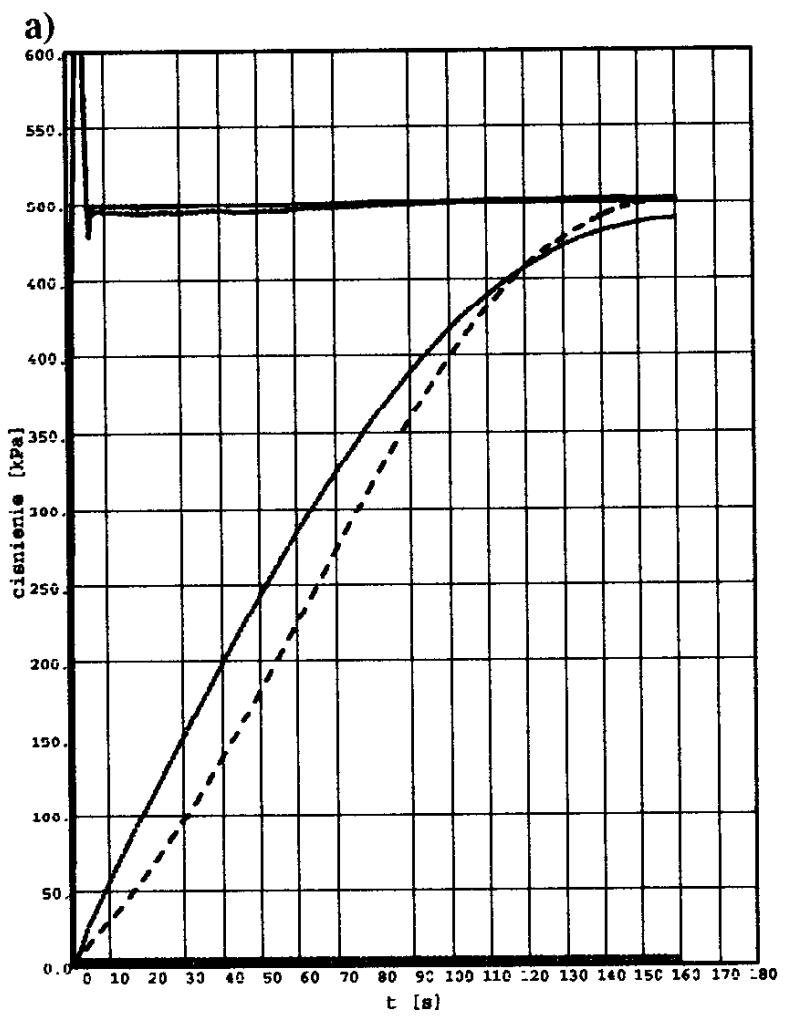

wspornika. Dokonano również pomiarów specyficznych zdarzeń nie występujących w eksploatacji zaworu, w celu lepszego rozpoznania jego charakterystyk. $\mathrm{W}$ artykule przedstawiono porównanie jedynie wybranych wyników doświadczalnych i symulacji.

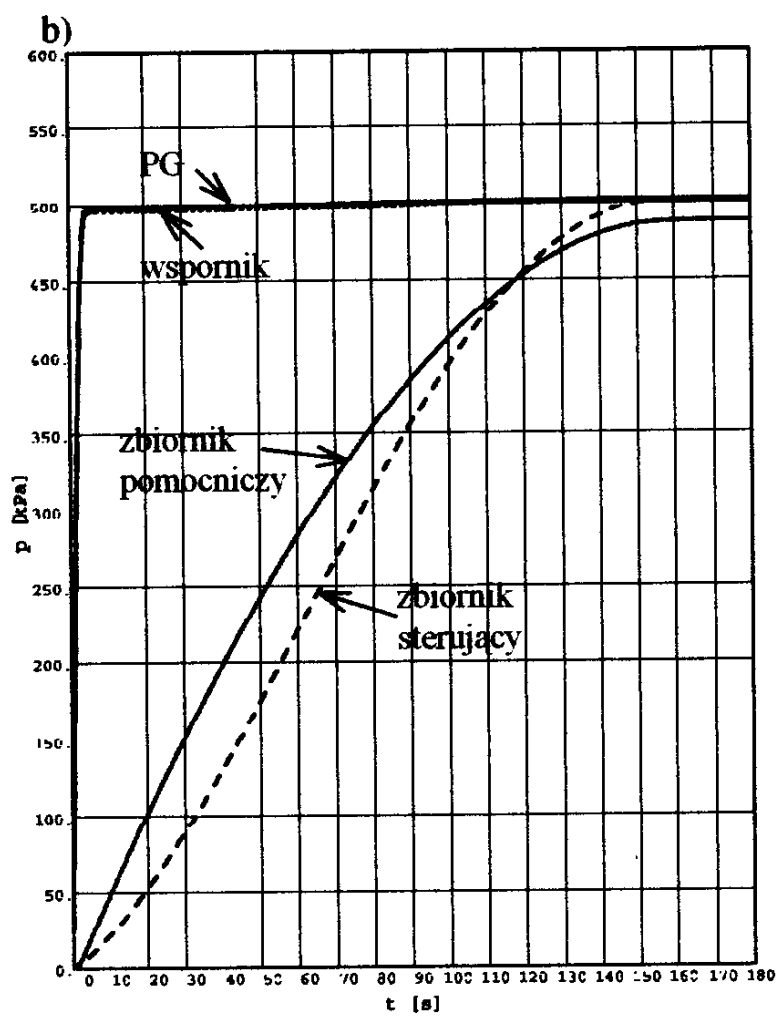

Rys. 9. Pierwsze napełnianie układu: a) pomiar, b) symulacja 
a)

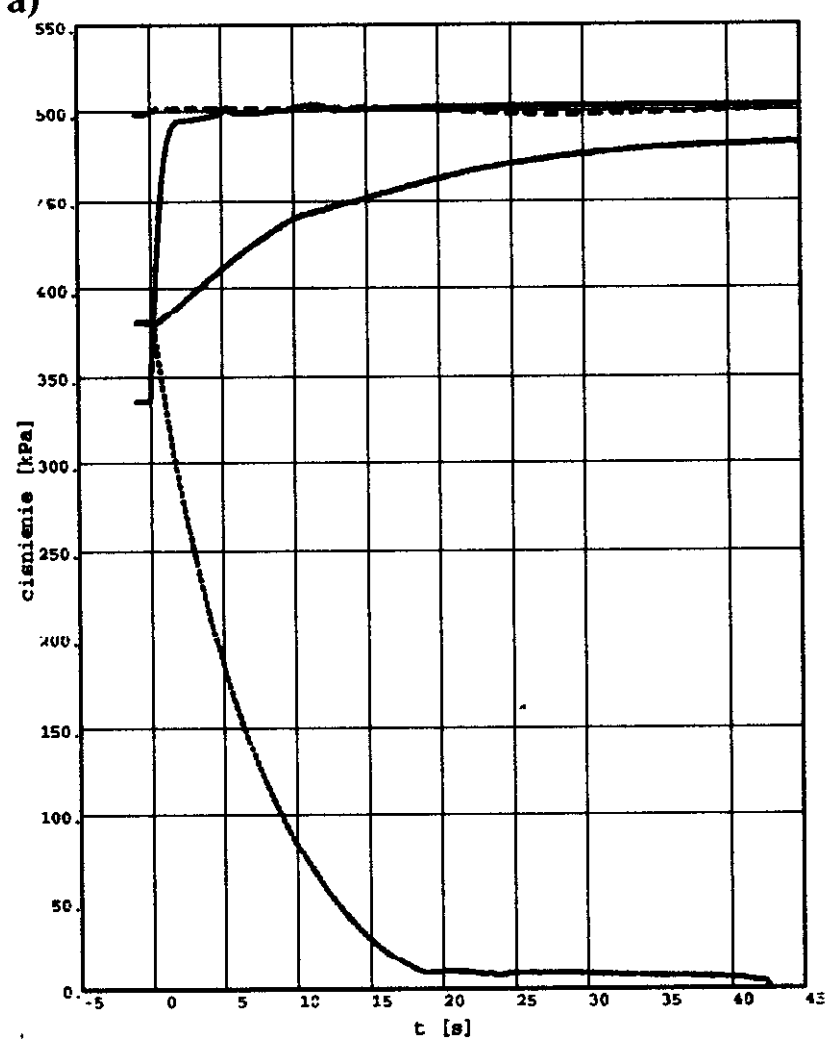

b)

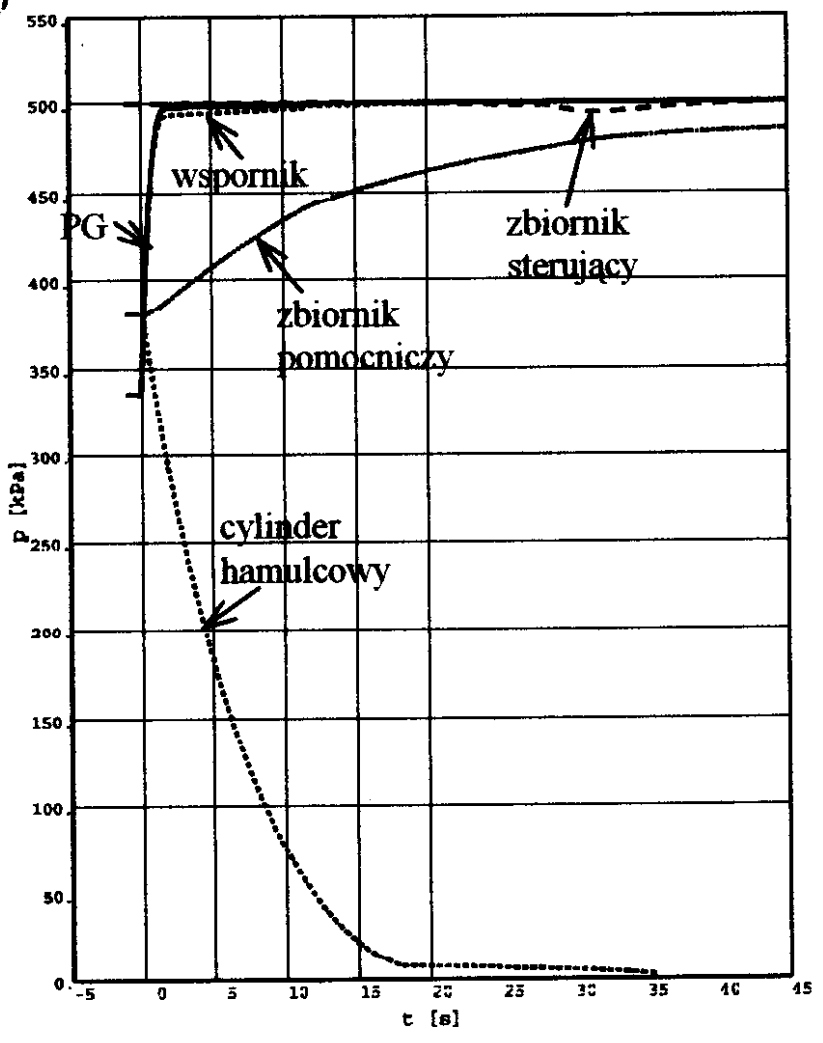

Rys. 10.Odhamowanie: a) pomiar, b) symulacja

a)

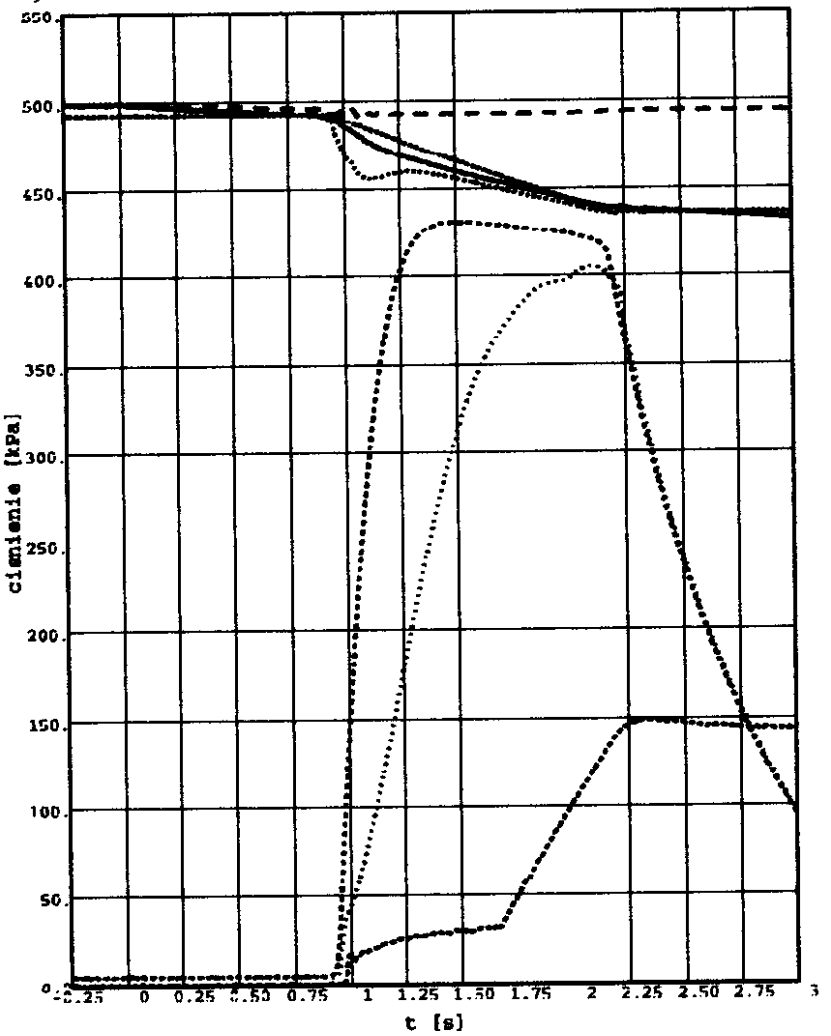

b)

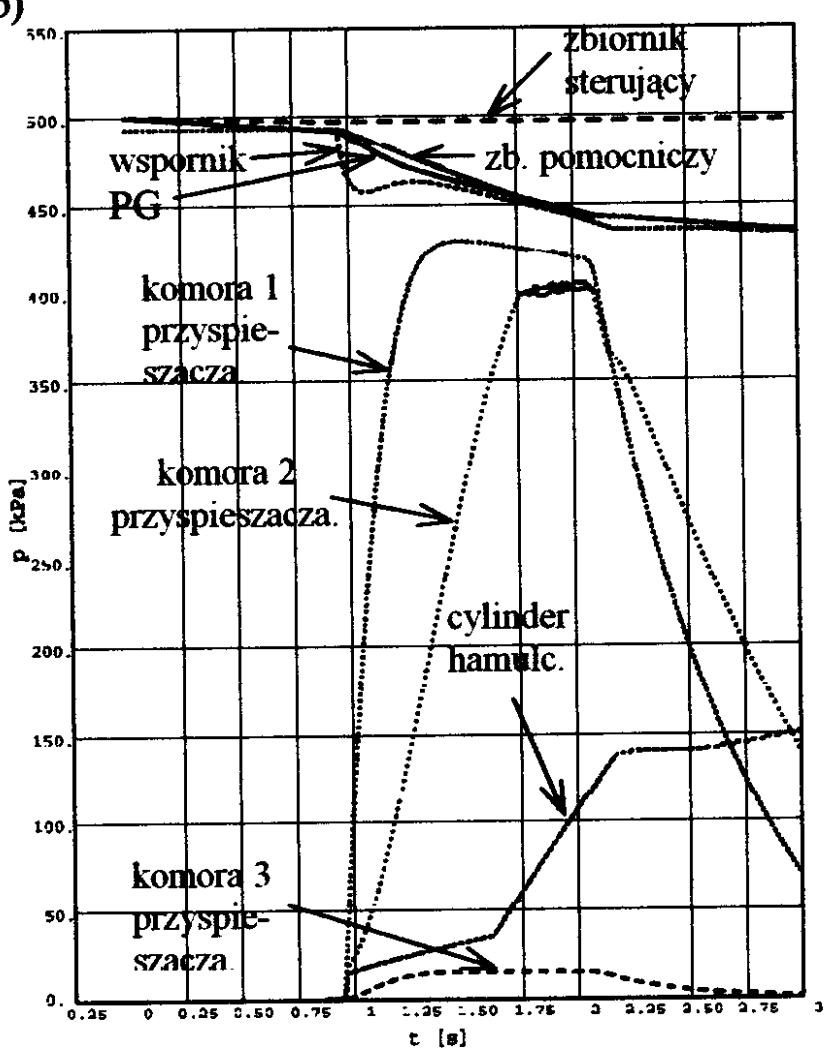

Rys. 11. Początek hamowania: a) pomiar, b) symulacja 
Nie dokonano korekty modelu dla uzyskania najlepszej zgodności symulacji i doświadczeń. Można tego dokonać np. stosując bezgradientową metodę optymalizacji, zaimplementowaną przez autora do wykorzystania z pakietem symulacyjnym BLOK. Jedynie sztywność sprężyny liniowej nr $2 \mathrm{w}$ modelu szczegółowym dobrano (rzeczywista jest nieliniowa), aby moment uruchomienia przyspieszacza $\mathrm{w}$ symulacji był zbliżony do pomierzonego.

Porównanie wyniku symulacji i pomiaru przedstawiają rysunki 9 do 11. Jak z nich wynika uzyskano jakościowo dużą zbieżność wyników, różnią się one niewiele ilościowo. Podstawową różnicą jest spadek ciśnienia $\mathrm{w}$ objętości przyspieszacza nr 2 na rys. 11 . Jest on w pomiarze dużo szybszy, niż w symulacji. Zapewne uszczelnienie wargowe membrany komory przyspieszacza $\mathrm{w}$ danym zaworze pozwala na jednostronny przepływ powietrza. Celowo nie dokonano korekty modelu.

\section{Zakończenie}

Przedstawiono zależności teoretyczne i sposób modelowania dyskretnych układów pneumatycznomechanicznych na przykładzie zaworu rozrządczego Est3f wraz z elementami towarzyszącymi. Przedstawiono modele o różnej dokładności (wybranej ze względu na cel analiz symulacyjnych) i nakładzie pracy na analizy symulacyjne. Większą część tej pracochłonności zajmuje przygotowanie modelu.

Porównanie wyników symulacji przedstawionych modeli pokazuje, że model funkcjonalny udokładniony jest wystarczający do prawie wszystkich typów symulacji. Jedynie działanie przyspieszacza w przypadku zaworu Est3f nie jest w pełni satysfakcjonujące; wymaga ono modelowania ciagłej funkcji domykania się zaworków, co można zrealizować albo w modelu uwzględniającym dynamikę mas ruchomych (model szczegółowy) lub przez wykorzystanie obliczenia ciągłej funkcji domykania zaworu na zasadzie bezinercyjnej opisanej w [6] jako blok PRZEKL1.
Przedstawione porównania wyników symulacji i pomiarów pokazują, że dokładniejsze metody dają na tyle porównywalne wyniki, iż mogą być pomocne na etapie projektowania. Przy użyciu dokładnych metod modelowania można np. analizować warianty konstrukcji w celu wybrania najlepszego rozwiązania.

Tworzone są przez autora modele kolejnych typów zaworów rozrządczych. Celem ich tworzenia jest możliwość wykorzystania modeli w różnorodnych symulacjach całopociagowych.

\section{Literatura}

[1] Gasowski W., Piechowiak T.: Matematyczny opis zjawisk zachodzacych $w$ układzie pneumatycznym hamulca pociagu. Pojazdy Szynowe, nr 1/2004.

[2] Idelchik I. E.:Handbook of Hydraulic Resistance, 3rd Editon. Jaico Publishing House, 2005.

[3] Piechowiak T., Kaluba M.: Wplyw napetniania przewodu głównego wysokim ciśnieniem na proces luzowania pociagu. XIV Konf. Nauk. POJAZDY SZYNOWE 2000, Kraków 2000r.

[4] Piechowiak T.: Ksztattowanie optymalnej charakterystyki sterujacej procesami napetniania $i$ opróżniania przewodu głównego. Instytut Pojazdów Szynowych „,Tabor” w Poznaniu, grudzień 2001r. Projekt badawczy KBN Nr 9T12C01018. Praca niepublikowana.

[5] Piechowiak T.: Modelowanie uktadu mechanicznego $w$ urzadzeniach pneumatycznych hamulca. Pojazdy Szynowe, nr 3-4/2004.

[6] Piechowiak T.: Metoda matematycznego modelowania uktadu pneumatycznego hamulca pojazdu szynowego. Pojazdy Szynowe, nr 3/2005.

[7] Szargut J. Termodynamika. PWN, Warszawa 1985.

[8] Tuliszka E.: Mechanika plynów. Wydawnictwo Uczelniane Politechniki Poznańskiej, Poznań 1969. 